\title{
Hemifacial hyperplasia
}

INSERM

\section{Source}

INSERM. (1999). Orphanet: an online rare disease and orphan drug data base. Hemifacial hyperplasia. ORPHA:141145

Hemifacial hyperplasia is a rare morphological anomaly of the maxillofacial region characterized by unilateral overgrowth of all facial structures (bone, soft tissues, teeth), called true hemifacial hypertrophy, or overg rowth of one or more but not all facial structures, called partial hemifacial hypertrophy. It may be isolated or related to some syndromes (e.g. Beckwith-Wiedemann, Proteus, Klippel-Trenaunay-Weber, McCuneAlbright syndrome, Neurofibromatosis type 1). It may be associated with airway obstruction, sensorineural hearing loss or swallowing difficulties. 